\title{
Chapter 10 \\ Voluntary and Forced Return Migration Under a Pandemic Crisis
}

\author{
Zeynep Sahin Mencutek
}

\subsection{Introduction}

The Covid-19 pandemic has had an impact on all types of mobility and migration dynamics, including return migration. The almost immediate closing of borders in the face of pandemic lead to the panic mobility of those returning home across the globe. In addition to visitors and tourists, internal and international migrants returned to their country or city of origin. Lockdown measures prevent many migrants from earning a living from their unsecured, temporary, and informal jobs. The pandemic also brought evident risks for highly-skilled migrants' access to healthcare, financial security, and social protection, forcing them to consider the return option. The crisis, like economic recession and pandemics, makes migrants' aspirations and decision-making far more complex than in 'normal' times. Migrants' decisions are marked by deep dilemma between staying and returning.

Against his background, the chapter addresses the following questions: how and to what extent has the pandemic triggered the returns of migrants? What are the diverging characteristics of returning compared to other crisis situations and before pandemic times? How do receiving and sending countries respond to returns? How does the pandemic influence migrants' aspirations about staying and returning? Does the pandemic create different sets of challenges for irregular migrants and regular migrants?

An emphasis on returns offers insights to evaluate changing characteristics of migration in 'pandemic times'. It will also contribute to revisiting discussions on dichotomies in the return discourse such as voluntary versus forced, return assistance, and reintegration during and after the pandemic crisis. The chapter is based on desk research and analysis of the scholarly literature, reports, and grey literature

Z. S. Mencutek $(\bowtie)$

Bonn International Center for Conversion, BICC, Bonn, Germany

Ryerson University, Toronto, Canada 
from international organisations (particularly the International Organization of Migration, IOM), civil society reports, scientific blogs, and media reports. Data on returns are based on information provided by the Mixed Migration Centre (MMC).

The chapter starts with a brief review of literature on return migration. It then moves to the recent scholarship addressing the crisis - particularly in the global economy - and its impact on returns. The next section explores how the pandemic influences the multiple facets of the migrant returns. After presenting the main patterns during the pandemic, this section introduces two subsections to further elaborate on the topic: the first focuses on the logistics of returns, with special attention to IOM's involvement in the assisted return operations; the second provides some insights into the complexity of return decisions, drawing mainly from secondary sources. The challenges in which returnees encountered on the way and after return are addressed next, and the chapter concludes with a summary of main trends and some projections.

\subsection{An Overview of Return Migration Scholarship}

Return is a broad concept that is variously defined. An encompassing definition refers to "the movement of a person going from a host country back to a country of origin, country of nationality or habitual residence usually after spending a significant period of time in the host country whether voluntary or forced assisted or assisted or spontaneous' (IOM, 2011). The scholarship on return migration overwhelmingly draws from the experiences of international labour migrants, while refugees, asylum seekers, and internally displaced people (IDPs) have been paid less attention.

Existing studies seek to theorise return migration (Cassarino, 2004; Carling \& Pettersen, 2014; King, 2015). Mapping the plethora of studies shows that there are no single reasons explaining return aspirations, decisions, the actual return process, and reintegration. The approaches on return aspirations and decisions diverge based on the level of analysis (individual, household, state), the primary motives driving return (economic aspects, non-economic aspects) as well as micro or macro dimensions. As the migration processes have often been explained by push-pull factors highlighting economic reasons, return migration scholarship also adopts a similar approach.

The first strand of scholarship focuses on motivations for returns, also called intentions and aspirations. It should be noted that return motivation is not the exact predictor of actual returning. Although most migrants initially intend to return, they rarely do. Studies on return aspirations draw largely from neoclassical economics, labour economics, and transnationalism literature (Waldorf, 1995; De Haas et al., 2015). Large-N studies about migrant workers find that failure of integration in the country of residence is a factor, prompting return intentions and pushing for returns. This is because labour market participation, education, and job satisfaction are expected to increase migrants's stay intentions (De Haas et al., 2015; Waldorf, 1995). 
Return also happens when migrants miscalculate the costs of migration and when they realise they are not able to access high standards of living, higher income, or accumulate saving (Cassarino, 2004: 255; Dumont \& Spielvogel, 2008: 178). Although the level of education is not directly related to the tendency to return, those who work below their qualifications may have a higher tendency to return.

In return decisions, the economic and education variables interact with other factors such as the initial migration plans, expectations upon return, demographic characteristics, gender relations, and family issues, among others. Quantitative studies specify demographic characteristics such as age, lifecycle, generation, gender, number of dependents, household decision-making, and lifestyle reasons to explain likelihood to return (De Bree et al., 2010; De Haas \& Fokkema, 2010). For example, studies on return migration to central and eastern Europe find that 'returnees are predominantly male, young, not married, and with a medium or high level of education' (Zaiceva \& Zimmermann, 2012, 2). A return move may also occur when any pre-defined objectives are achieved, such as completing education (or children's education), accumulating a certain amount of wealth or gaining citizenship or pensions. Duration of residence in the host country and years prior to retirement may impact on return decisions (Waldorf, 1995; Dustman, 2003). So, as Cassarino (2004) notes, migrants consider return when they achieve migration-related goals and targets; return is thus a 'calculated strategy' of both migrants and migrant households.

Return decisions can be also explained by pull factors related to the home country. Factors that may influence migrants' decision-making to return include investments and social ties to the homeland, political and economic opportunities; family demands; identity-driven motivations such as feelings of belonging to the homeland; and ethnic (Wang \& Fan, 2006; De Haas et al., 2015; Skrentny et al., 2007).

All these factors are neither related in a predictable way nor independent of each other, making any analysis quite complex (Carling \& Pettersen, 2014). To illustrate, based on the cases of Eastern European migrant workers' return to their home countries, Anzelika Zaiceva and Klaus F. Zimmermann found that

\footnotetext{
If migration is temporary, the decision to move will not only be based on immediate and future incomes in the destination, but also on the expected future returns in the country of origin. The main motives for return include preference for consumption in the home country, family and other networks at home, taking advantage of differences in relative prices between host and home countries (high wages abroad and low prices at home), and the possibility of accumulating human capital abroad, the returns to which are higher at home. (Zaiceva \& Zimmermann, 2012: 2)
}

Individual factors also interact with the host country's policies. In a recent article on Bolivian migrants' return from Spain, Raquel Martínez-Buján (2019) argues that 'migrants' decisions to return home are embedded in the gendered allocation of economic and reproductive responsibilities and patriarchal ideology' as well as in fluctuating Spanish migration policies restricting circular migration and allowing citizenship acquisition (p. 3105).

In addition to analysing factors that shape return intentions and decision, the second strand of return migration scholarship - which emerges more in the field of 
Refugee Studies and Forced Migration - raises the question of how returns are organised. Focusing on the return of refugees, asylum seekers, and IDPs, existing studies question the pre- and post-return assistance, practices, and interventions of international agencies, home and host states (Bascom, 2005; Omata, 2013; Iaria, 2014; Arias et al., 2014). Drawing from the existing practices, several studies offer key dimensions of better return programmes such as compliance with legal principles (safety, voluntariness, dignity), livelihood development, and equal citizenship within a nation (George et al., 2016; Frank, 2017; Gerver, 2018). In recent years, much interest has been dedicated to examining Assisted Voluntary Return and Reintegration (AVRR) schemes adopted by European countries to facilitate the return of rejected asylum seekers and those who voluntarily return (Lietaert et al., 2017; Lietaert, 2019; Koser \& Kuschminder, 2017).

The third strand of return migration focuses on reintegration of returnees. The studies examine the impact of several factors on returnees' reintegration, including human capital and financial capital; resource conditions, particularly livelihoods; economic opportunities and housing; personal networks, social contacts and existing power relations; reception by host communities; and traditions and values in the home country (De Bree et al., 2010; Ruben et al., 2009; Iaria, 2014; Cassarino, 2004). Despite the significant insights these studies provide, we do not yet have adequate knowledge about how crisis situations like economic recession or a pandemic influence migrants' return aspirations, actual returning practices, and reintegration.

\subsection{Returning Home in Times of Crisis}

The impact of crisis over a return migration had received limited scholarly attention until the global economic crisis, also called the Great Recession. Drawing from the mainstream literature on return migration and labour migration, growing scholarship has focused on the 'crisis returnees' emerging from 2007 to 2011 (ApsiteBerina et al., 2020). These studies engaged with the hypothesis that 'the economic crisis and the resulting situation on the labour market in the immigrant-receiving countries have a negligible influence on the migration decisions (including return and onward migration)'. A number of large- $\mathrm{N}$ and single case studies cover return dynamics during economic crisis in Europe (Smoliner et al., 2012; Machnis-Walasek and Organiściak-Krzykowska), North America (mainly US-Mexico) (Buznego et al., 2020), and South and East Asia (Zachariah \& Rajan, 2010).

The main finding for internal European migration is that no mass return migration was observed because the economic situation in migrants' home countries also worsened, however, emigration slowed as migrants adopted a 'wait-and-see' strategy during this period (Holland et al., 2011; Koehler et al., 2010). Nevertheless, the crisis has given momentum to accelerate planned returns and onward migration to elsewhere (Koehler et al., 2010; Eurofound, 2012). Some migrants from new EU member states (central and eastern European countries) working in the old member states of the EU (known as the EU15 countries) had to return home. The Baltic 
states, Slovakia, and Poland had the largest proportions of returnees during the crisis period. A prominent quantitative study highlights that the probability to return emerges as larger for individuals with middle and higher educational attainments. Also, migrants who are males, single, and older, and those without children are more likely to return, relative to other migrants in the same destination countries (Zaiceva \& Zimmermann, 2012). Returns during crisis occurred due to economic reasons - mainly job loss - because migrants often are employed in sectors most affected by the crisis such as services, construction, and retail. Migrants experienced bigger rises in unemployment compared to natives. Also, some of these returnees initially hold temporary intentions of staying abroad or feel emerging social pressures fuelled by economic difficulties in destination countries. As in the case of Polish returnees from the UK in this period, migrants 'might not intend to return due to the crisis, with the main reasons for return in this case also being family related' (ibid., 9) In the case of returnees to Lithuania, family and cultural motives appear as the most important for return decisions (ibid).

Aside from several push factors for returning home during a crisis, there are also pulling factors that make staying a more rational decision under some conditions. As regional or global economic crisis affects both receiving and sending countries, the economic situation at home might become worse than that in the destination. Some migrants thus delayed return; unemployed migrants ruled out the return option due to uncertainty about the possibility to re-enter the destination country in the future. Despite job loss, the presence of established networks abroad (feasibility of re-migration to elsewhere), migrant-to-migrant solidarity, expansion of social assistance or transitional measures in a way to include migrants, and a sense of belonging and security or having settled family (Pusti, 2013) acted as factors deterring returns. Some migrants chose to migrate onwards to other destinations less severely affected by the recession. Even in instances of return, these did not necessarily mean the end of the migration trajectory, rather potential repeat and circular migration seem to be the case. Many returnees have strong aspirations for repeat emigration (Zaiceva \& Zimmermann, 2012, 9).

Several other case studies such as research looking at the impact of the Greek debt crisis on the decision of Albanian migrants to return (Kerpaci \& Kuka, 2019), the return motivations of Romanian healthcare staff (Roman \& Goschin, 2014), highly educated Polish emigrants (Machnis-Walasek \& Organiściak-Krzykowska, 2014), Romanians and Latvians (Apsite-Berina et al., 2020), or Bolivians' return from Spain (Martínez-Buján, 2019 found similar patterns to those discussed above.

Existing research on the impact of financial crisis provides us some insights for examining return dynamics during pandemics, as McKee and Stuckler rightly note:

The Covid-19 pandemic is, first and foremost, a health crisis. However, it is rapidly becoming an economic one too... because of... reduction in economic activity reduces the circulation of money and, with it, tax revenues... hits individuals and families, who may see their income plummet catastrophically... Once they have depleted their financial reserves, companies close, with consequences for their owners, employees, and suppliers. $(2020,1)$ 
Although conditions of economic crisis display similarities with pandemics, there are some differences too. First, the pandemic created serious health risks for migrants and returnees, including the potential of spreading it to the communities on return. Second, immediate border closures to control the spread of Covid-19 generated more restrictions over all types of mobilities - which was not the case in the time of economic crisis. Third, migrants' exits from or re-entry to may not be feasible, hindering the circular migration patterns and embracing stranding or a 'wait and see approach'. Fourth, the pandemic hit almost all countries, while economic crisis was more region-specific. Given this context, the pandemic has particular sets of impacts on return migration that can be conceptualised as crisis-return. The term implies that crisis shapes return intentions and decision, the actual returning practices, the involvement of state and international actors, and the conditions encountered by migrants upon return as will be discussed below.

\subsection{The Pandemic's Impact on the Acceleration of Returns}

The Covid-19 crisis prompted many migrant workers, irregular migrants including asylum seekers, and those stranded in transit zones to evaluate the option of returning to their home countries. Actual returns occur across the globe with small and high numbers according to news and reports, mainly published by the IOM and research institutions like the Mixed Migration Center (MMC).

India, the country of the highest number emigrants in the world, observed one of the biggest return movements of international and internal labour migrants. Hundreds of thousands of Indian citizens working in the Gulf Countries as well as the US, the UK, Spain, and Italy had returned to India by 22 March when it restricted all international travel. Reports claim that 'as many as 4,56,431 expatriates wanting to return home registered on the government-run Non-Resident Keralites Affairs department website in April. According to the state government data, over 90,000 have so far been evacuated' (Babu, 2020). Indian journalists and scholars identify this movement as a reverse migration (Premkumar, 2020; Menon \& Vadakepat, 2020). Moreover, a half-million internal migrants literally walked to back to their home villages to survive as they lost daily earnings in the large cities.

Some other massive returns occurred in South America and Europe. One of the largest return movements was that of an estimated 15,000 Venezuelans (Polanco \& Sequera, 2020). Some $90 \%$ of Venezuelan refugees and migrants in Columbia and Peru reported losing income due to the pandemic - a much higher percentage of job losses than in other regions (MMC, 2020a). In Europe, tens of thousands of Ukrainians working in Poland, the Czech Republic, Italy, and elsewhere rushed to return home because of business shutdowns and economic contraction (Scollon, 2020). Seasonal workers from Romania, Poland, and Bulgaria who work in farms and food plants in Germany, Australia, and the UK had to return to their origin countries in March, while in early summer they were asked back to the destination countries as much-needed agricultural labour (Gherasim, 2020). 
One of the largest movements observed was the 'spontaneous' return of irregular Afghan migrants from Iran and Pakistan. It is the pandemic's best-documented return because it had been underway before the pandemic. While some of these returns occurred due to the loss of income (MMC, 2020a), others can be attributed to the inability to continue the migration journey due to the increased risk of detention and deportation. From January to September 2020, a total of 576,801 Afghans had returned - 571,800 from Iran and 5001 from Pakistan. Parallel to rising Covid-19 cases in Iran, these spontaneous returns of stranded migrants from Iran to Afghanistan increased marginally. For example, while the total number of returns was only 9478 in the week of 23-29 February, the figures peaked at 62,341 for the week of 15-21 March (IOM, 2020). A similar sharp rise was also observed in the assisted returns of Afghans from Iran, organised by the IOM; whereas 527 Afghans returned in the week of 23-29 February, their number rose to 3300 in the week of 15-21 February (IOM, 2020).

In general, some migrants returned using their own resources, while others had to wait for their governments to fly them home as they lacked financial resources or faced border closures (Gulf News, 2020). Migrant workers' returns are often labelled 'voluntary returns' in the reports by the IOM, research institutions, and academic publications (Menon \& Vadakepat, 2020, 2), although they lacked another option, raising questions about how this return is 'voluntary'. In addition to those able to return, many migrant workers were stranded or did not find opportunity to return (Scollon, 2020). Some of those stranded became more vulnerable to exploitation and had to take up or continue to work in employment in conditions with increased exposure to Covid-19 such as delivery and food processing (IOM-Abuja, 2020). Many migrants, unfortunately, died of Covid-19 - for example, 296 expatriates from Kerala who died in West Asia - thus adding other sets of difficulties for families of migrants such as bringing home the deceased's body when commercial flights resume (Babu, 2020).

The difficulties in logistics of migrant returns spurred some migration governance arrangements, with the involvement and funding of international organisations. Home countries with fewer resources to arrange charter flights and host countries looking for the quick return of migrants cooperated with the IOM in developing solutions, as will be elaborated below.

\subsection{Logistics of Returns for Stranded Migrants: The IOM's Interventions}

Many migrants were stranded for some time in transit points (or buffer zones) of several lands and maritime migratory routes such as Turkey, Greece (eastern Mediterranean), Libya (central Mediterranean), Niger (Sahara route), Djibouti, and Yemen (East African route to Saudi Arabia), Kenya (southern route) and elsewhere. According to reports, among these transits, the highest percentages of trapped 
migrants for a time were in Libya, Niger, and Kenya (MMC, 2020b). Some of these migrants had to return after being stranded for months, although they rarely changed their actual plan of migration (MMC, 2020b).

Between Spring and Fall 2020, some migrants stranded in transit were returned with the assistance of the IOM because they were neither able to reach their destination nor to return home (IOM-Djibouti, 2020). The IOM worked with regional governments in Africa, Latin America, and Asia to facilitate the return of stranded migrants, opening 'humanitarian corridors' by collaborating and negotiating with the origin and host countries (IOM-Freetown, 2020). In Latin America, the return operations emerged as part of the IOM's Assisted Voluntary Return and Reintegration Programme (AVRR) (IOM-Belize, 2020). In Africa, IOM interventions were part of the AVRR and the EU-IOM Joint Initiative for Migrants Protection and Reintegration. These programmes are funded by the EU Emergency Trust Fund for Africa (IOM-Freetown, 2020) as well as donor countries such as the US, Germany, Norway, Denmark, and the Netherlands. From March to May 2020, the IOM facilitated the voluntary return of over 16,500 migrants under the EU-IOM Joint Initiative for Migrant Protection and Reintegration (IOM-Nigeria, 2020). The operations continued. The majority of assisted return operations were in Africa's transit points, as shown in Table 10.1.

Moreover, the IOM worked with the World Health Organization (WHO) to strengthen health surveillance measures at points of exit and entry of returnees, including the distribution of personal protective equipment, pre-departure testing for Covid-19, rehabilitation of screening and isolation facilities, and training of frontline border officers on infection prevention and control (IOM-Sudan, 2020). For instance, some 5822 persons returned from the US and Mexico to Honduras (IOM-Honduras, 2020) were provided post-return assistance. Similar support was given to 14,000 Mozambican returnees from South Africa (Africanews, 2020).

In almost all IOM operations, both IOM regional staff and coordinating home and host state officers underlined compliance with the principles of returns: voluntariness, safe and dignified return. A review of news published in IOM's official website shows that many of the country representatives (called 'Missions' in IOM's terminology) emphasised how the IOM assisted returns by invitation and ensures safe and dignified return. It should be underlined that the published quotes below from country representatives are preselected by the Media and Communication Division at IOM Headquarters. Thus, it is not surprising that they align with the overarching discourse reflected in the IOM's ongoing information campaigns and communications with crisis-affected communities and governments. Like all political discursive practices, press releases about return operations of stranded migrants during the pandemic may have a legitimising function. The quotes chosen for inclusion in press releases exemplify this attempt at justification by appropriating a rights-based terminology.

For example, Michele Bombassei, IOM Regional Senior Programme Coordinator for West and Central Africa, legitimised the necessity of IOM's interventions by underlining the terminology on safe and dignified return as well as taking action after invitation (rhetoric). He reported: 
Table 10.1 IOM-assisted return operations during the Pandemic

\begin{tabular}{l|l|l}
\hline Returned to/Nationality & Stranded in/Returned from & $\begin{array}{l}\text { Total } \\
\text { number }\end{array}$ \\
\hline Ethiopia & $\begin{array}{l}\text { Sudan, Djibouti, Somali, Saudi Arabia, } \\
\text { Kuwait, Lebanon }\end{array}$ & 17,000 \\
\hline Sudan & Middle East, North Africa, Asia & 15,000 \\
\hline $\begin{array}{l}\text { Mali, Guinea, Burkina Faso, Benin, } \\
\text { Nigeria, Cameroon }\end{array}$ & Niger & 2800 \\
\hline Ghana and Guinea & Niger & \\
\hline Mali & Niger & 61 \\
\hline Mali & Niger & 159 \\
\hline Mali & Algeria & 179 \\
\hline Côte d'Ivoire, Guinea, Liberia & Algeria & 84 \\
\hline Ghana & Libya & 114 \\
\hline Malawi & South Africa & 118 \\
\hline Nigeria & Lebanon & 111 \\
\hline Sierra Leoneans & Senegal & 165 \\
\hline Uganda & Saudi Arabia (female migrant workers) & 100 \\
\hline Chad & Cameroon (students) & 2000 \\
\hline Somalia & Iran & 13 \\
\hline Mongolia & Czechia & 250 \\
\hline Nepal & Cyprus & 63 \\
\hline Bndia & Cyprus & 21 \\
\hline Selize & El Salvador & 13 \\
\hline
\end{tabular}

Source: Author compilation from IOM press releases: IOM-Addis Ababa 2020; IOM-Accra 2020; IOM-Bamako 2020; IOM-Niger 2020; IOM-Algiers 2020; IOM-Pretoria 2020; IOM-Abuja 2020; IOM-Freetown 2020; IOM-Kampala 2020; IOM- N'Djamena 2020; IOM- Mogadishu 2020; IOM-Nicosia 2020; IOM-Ulaanbaatar 2020; IOM-Belize 2020; IOM-Sudan 2020

An increased number of migrants and governments have approached IOM for support in the organization of return operations to countries of origin...Governments are approving exceptions to the closure of borders for IOM to operate and to support the safe and dignified return [italics added] of stranded migrants. (IOM-Freetown, 2020)

The IOM and collaborating partners seem certain about the voluntariness of the returns. Chief of Mission of IOM in South Africa Lily Sanya stressed the same voluntariness aspect:

Since the beginning of the pandemic, IOM and our partners have provided voluntary return support to approximately 400 nationals from various countries in the region. This is a continuation of our support to vulnerable migrants that decide they would be better off returning home. (IOM-Pretoria, 2020)

The continuation of return operations in new formats and narratives during the pandemic might be expected to aim at strengthening IOM's visibility and credibility. They may bring the organisation more leverage in migration governance in general by carrying out the critical role of negotiating/operating further returns that have been the goal of regional and global migration governance (see UN Compact, 
2018; EU Pact, 2020). The consistency of the statements delivered by different IOM officers confirms the previous findings that IOM has 'an intra-organisational cohesion which contributes to the power and authority of the organisation as related to AVRR programming' and that 'the IOM has become a key source of power and authority in the pursuit of global forms of migration governance' (Smith, 2019, 1).

While the pandemic opened a space for the IOM to operate new modes of return operations, it had to suspend or downsize formal AVRR programs in Europe. For instance, only 432 migrants on Greek islands voluntarily returned to 20 countries of origin via commercial flights with the IOM's assistance from March to mid-July 2020 (IOM-Athens, 2020). However, since mid-July 2020, several EU member states resumed returns with the IOM. The first 'voluntary returns' were facilitated by IOM in Greece and the Hellenic authorities, in coordination with IOM Iraq and the diplomatic corps, for the return of 134 Iraqi nationals who had been residing on the islands of Lesvos, Samos, Kos, Chios, and Leros, as well as the Greek mainland for several months and wished to return to Iraq (ibid.). Moreover, in August 2020, after a 6-month hiatus due to Covid-19 border closures, the IOM resumed its AVRR programme from Niger to Gambia, by returning 26 Gambian migrants who in the IOM's transit centres in Niger (IOM-Banjul, 2020).

\subsection{Reasons of Return}

Migrants' aspirations and decisions for return have always been a complex process, as discussed in the literature overview above. Covid-19 created conditions of severe financial crisis for many migrants, thus 'returning home' emerged as a desired or required urgent decision. A review of the independent think tank Mixed Migration Centre's weekly snapshot reports shows that the 'Covid-19 was cited as a main driver of return' in the survey questionnaire filled by returnees in Asia and Latin America. The survey was conducted with 7000 participants in five regions and 14 countries between April and July 2020 to collect data about the impact of Covid-19 on migrants and refugees' (Mixed Migration, 2020). According to other research and news reports, returns are most likely to happen due to the income losses and consequent deterioration of living conditions in the host countries.

The impact of Covid-19 on global trade and the resultant shocks to national economies have put both public and private businesses at huge risks. Distressed companies - especially those in 'recession-hit' sectors such as construction, manufacturing, and services - have either suspended or slowed their activities (Menon \& Vadakepat, 2020, 7; Zeeshan \& Sultana, 2020, 135). Accordingly, lockdown measures prevented many labour migrants from earning a living due to the business shutdowns, wage cuts, outstanding back pay, paused or cancelled employment contracts, being placed on paid or unpaid leave, and asked to vacate their accommodations (Babu, 2020; Kuttappan, 2020). The pandemic reduced possibilities of finding new jobs not only due to the consequences of Covid-19 on the national economies but also because of governments' greater focus on prioritising the employment of 
own nationals to protect them in the shrinking labour market (Menon \& Vadakepat, 2020). From the policymakers' perspective, 'the common assumption is that labour migration is a temporary feature which in the event of an economic crisis can be simply "turned off," mitigating the effect on the national population and institutions' (Chang, 2014, 93). Thus, the policy environment is eager to encourage or force migrants to return until the crisis passes (Chang, 2014). States introduced relief packages that would partly compensate for worker salaries mainly for citizens, but rarely for the benefit of migrants (Zeeshan \& Sultana, 2020, 135).

Those working in temporary and informal jobs experienced greater deterioration of financial insecurity coupled with rising prices of essential goods. In addition to the loss of their livelihoods, they faced impediments in access to health facilities, sanitary items, and basics such as food, water, and shelter. Restricted economic activity to contain the virus's continued spread left many migrants without money to buy food or pay rent (Polanco \& Sequera, 2020). The social support and protection mechanisms became more limited for migrants, while signs of increasing stigmatisation and xenophobia emerged. Some other factors pushing returns include the desire to unite with their families and concern for the safety of their families during this emergency.

Some snapshots from interviews with returnees about triggering factors are found in IOM's reports and scholarly publications. In their study, Zeeshan and Sultana quote one Pakistani returnee among some 60,000 working in the United Arab Emirates (UAE):

\footnotetext{
I have never felt so helpless in my lifetime. We neither had money, nor were our dues cleared by the employers we served. Also, there was no way of approaching them since most of the offices were closed and our movement was banned. Many of us had left with no mode of communication with their companies. Some of us started having symptoms of the Covid-19, but they were denied of any access to health facility. After repeated contact with the consulate, we were informed that the repatriation services are going on. (cited in Zeeshan \& Sultana, 2020, 141)
}

As quoted by the IOM in a press release on Covid-19, a domestic worker who returned from Lebanon to Ethiopia at the onset of the pandemic recalled her experience:

We lost our jobs, we struggled. Some of our friends fell ill...Things in Beirut are currently bad, and it was getting to a point where our lives were at risk. (IOM-Addis Ababa, 2020)

In another IOM press release, a Malawian migrant who returned from South Africa explained his reason for return:

Since the pandemic, I lost my job and source of income and support to my family. It's been too tough, so I decided to go back home and figure things out with the people I have missed all this time. (IOM-Pretoria 2020)

Additionally, as labour migrants' visas and work permits might expire due to job loss, they worried about being stranded or detained in already-overcrowded facilities where the virus spreads fast. In the case of Indian workers, the UAE government extended the validity period of residence visas (Travel News, 2020), while Kuwait used the lockdown period to crack down on workers over-staying their visas or 
permits (Irudaya Rajan \& Arokkiaraj, 2020). Some Gulf countries waited for the borders to reopen before repatriating or simply deporting migrants with a view to implementing a 'safe returns' policy, but others did not. Saudi Arabia deported 2870 Ethiopian migrants without regular papers to Addis Ababa between early March and April, while some 200,000 Ethiopians were expected to be deported in the following months (Endeshaw \& Paravicini, 2020).

The US administration banned immigration to the US and suspended processing of all work visas and appointments in March 2020. Migrants who were on vacation and in immigration processes were negatively affected by the hasty decision. As one Pakistani returnee from the US explained,

\section{I do think of returning back to work but my work permit has expired and the immigration processing is banned. My employer is directed by the US government to induct the local citizens keeping the national interest due to very high rate of unemployment. I neither have a way to get back, nor an opportunity in Pakistan due to immense downsizing in the job market. (quoted in Zeeshan \& Sultana, 2020, 137)}

For irregular and undocumented migrants, the pandemic brought more challenges for overall security and well-being. The pandemic-related measures reduced access to asylum applications and processes (MMC Asia, 2020) on the one hand, and increased the risk of forced returns, including detention, deportation, and pushbacks on the other. More frequent identity checks by police on the street for citizens' compliance with movement restrictions caused concern among undocumented migrants in destination countries, particularly those in Europe, that they may be detained or deported (Butterly, 2020). For undocumented migrants travelling to destination, the pandemic created an inability to continue the migration journey (MMC Asia, 2020), raising risks even higher due to the travel restrictions, border closures, and extreme danger along migratory routes. The continuing pushbacks on the sea borders of the EU's frontline countries like Greece, Cyprus, and Malta were justified by the risk to spreading the coronavirus, although the lack of rescue operations and assistance cost the lives of dozens of migrants (Butterly, 2020). The US allegedly deported thousands of undocumented migrants to neighbouring Guatemala and Mexico amidst the pandemic, including some who were infected with the virus (Dickerson \& Semple, 2020).

Although the impact of Covid-19 on return decisions was more detrimental for temporary migrant workers and irregular/undocumented migrants, highly-skilled migrants were also influenced by the pandemic into reconsidering their return plans. The imminent danger of 'job loss' or a 'lack of permanent residency' in the host countries led migrants to feel insecure (Menon \& Vadakepat, 2020). Anecdotal pieces of evidence from social media posts of immigrant groups illustrate that the highly-skilled migrants, such as engineers and those working in the multinational companies abroad, became the first candidates for layoffs in companies' downsizing, meaning the return of some to their countries of origin sooner or later. Even immigrant families with no financial stress worried about who would take care of their children if they contracted Covid-19, how their bodies would be sent to their countries of origin, and how they would attend the funerals of elderly parents if they 
passed. In such cases, Covid-19 seem to act as a catalyst for a return migration decision that had was being planned prior to the pandemic (ibid.).

\subsection{Challenges Faced During and After Return}

Previous research has documented how returning migrants encounter problems upon return and have to navigate socioeconomic, cultural, and moral differences and renegotiate transnational identities and intergenerational relationships (De Bree et al., 2010; Saar, 2018).

Returning due to Covid-19 has created additional challenges to alreadycontentious relationships about belonging and citizenship. Those making the return home because of the pandemic have faced severe difficulties. For example, many Afghans and Africans encountered troubles in crossing borders, movement within the country, and increased risk of detention and deportation throughout the return journey and reduced access to smugglers (MMC Asia, 2020).

Host countries and regions were not prepared to accommodate the sudden mass return migration economically by absorbing returnees into the labour market or providing services such as healthcare (Menon \& Vadakepat, 2020, 2). It is not unusual during pandemics to target those deemed 'foreign' and accuse them of 'importing disease'. Such prejudices were also aimed at return migrants (Munasinghe, 2020), prompting heated public discussion about the contribution of emigrants, their belonging, and citizenship. The following quote from a Sri Lankan emigrant in Italy reflects how the return discussion entangles the claims about citizenship rights of emigrants and emigrants' contribution to the economy of the home country.

These workers are Sri Lankans. They work in homes, outside, in factories... the money they make they send to Sri Lanka, nowhere else. They were born in Sri Lanka, where else can they go? These innocent young men and women work hard to send money to Sri Lanka, and you will happily eat from that money. How can you say, “when you are sick, don't come to Sri Lanka?" People who are living abroad are living in fear, not knowing what will happen. Without coming to Sri Lanka, should they jump in the ocean?. (ibid.,1)

Both prejudices and facts created an environment in which returnees were suspected and accused of bringing the disease with them as being 'super spreaders' (RFE, 2020). In India, regions having high emigration linkages with Gulf countries like Kerala and Tamil Nadu saw a sudden spike of Covid-19 cases in relation to the returns since April 2020 (Mitra et al., 2020). In response, in June 2020 the Indian state made Covid-free certificates mandatory for the returnees (Babu, 2020). Also, the local government restricted evacuation flights, considering that they do not have adequate facilities to tackle a surge in the number of returnees (ibid.). In Pakistan, it is reported that people testing positive on flights bringing migrant workers back from the UAE averaged $12 \%$ but that on some flights, the positivity rate shot up to $40-50 \%$ as many of these workers had lived in congested dormitories where the disease spread fast (Zeeshan \& Sultana, 2020, 137). 
In the case of Venezuelans, over 2100 migrants returning from Colombia were required to quarantine in unsanitary conditions at makeshift shelters near the border, reflecting the perceived threat from the influx to Venezuela's medical system, which has decayed during 6 years of economic collapse (Polanco \& Sequera, 2020).

Many returnees were unable to find work upon return to their home country, hit not only by the pandemic and lockdown measures but still reeling from previous crises. For example, Ukrainian returnees were not welcomed in their home country as unemployment is skyrocketing (RFE, 2020). Returnees thus experience impediments in accessing livelihoods and health services. As in the case of Afghan returnees, reduced access to work is higher for returnees; more returnees lost income and received even less assistance than refugees (MMC Global, 2020, 7-9). In the words of a male Afghan returnee:

When I was in Iran I was terrified by the news on Corona. Everybody was talking about the virus and all the dead people in the hospitals. It was like a war out there. When I returned to Afghanistan, I saw that the situation was worse here than in Iran. Many people are infected, but there is no proper health assistance available. (MMC Asia-May, 2020)

A Pakistani returnee explains his dilemma in returning:

After three months of unemployment and bewilderment, I reached home and thanked the Almighty and my family for all the efforts. I am now at peace that I am backing home, but the future is haunting me now. I used to send the remittances and hence could not save. Neither I have any savings to initiate any business, nor do I have any hope to get back to Britain to work. (quoted in Zeeshan \& Sultana, 2020, 137)

Home states and communities expressed concern that a huge influx of unemployed returnees would threaten the already fragile economic situation due to the sudden decline in foreign remittances and rising unemployment, collapse the health system due to the Covid-19 cases, and disturb demographic/social dynamics (Komireddi 2020; Zeeshan \& Sultana, 2020). Anxiety and even in some cases resentment against returnees made providing emotional support and feelings of belonging for returnees unavailable and reintegration harder (Zeeshan \& Sultana, 2020, 145).

Regarding belonging and feelings of migrants, return carried the risk of losing the hard-gained self-esteem, achievements, and recognition in their family and society from working abroad. They sought to sustain these values while returning home (Sabharwal \& Verma, 2020) and expected emotional support from their home communities (Menon \& Vadakepat, 2020, 2). For instance, many Indian returnees from UAE (Malayalees) felt neglected by both central and state governments. They believed that many lives 'could have been saved if people had been evacuated in the early days of the pandemic' (Babu, 2020). 


\subsection{Concluding Remarks}

As Anna Lindley rightly advocates, it is important to treat 'crisis and migration as contextualised processes, rather than isolated events, because migration is either a symptom or a cause of crisis' $(2015,1)$. The pandemic as a crisis has impact over various types of migration, including return migration.

During the pandemic, migrants' decisions are marked by the deep dilemma between staying and returning. Migrants face changing circumstances and conflicting motivations. Those migrants who continued to stay took risks for their health and safety as well as several layers of uncertainty as they might be unemployed due to economic downturn, running out of money, and not being able to send remittances to their homes. Returnees took the risks of returning to a life of uncertainty, not being able to go back again to the country where they worked, not completing their migration project, and encountering stigma in the country of origin as importers of the virus. Hyperinflation, poverty, unemployment even violence in the countries of origin have all loomed as highly possible prospects. Rational calculations, fears, concerns, and emotions are all mixed up to make immigrants reconsider multiple dimensions of staying and returning.

Data from this study can be shaped into a tentative typology (Table 10.2). The typology illustrates that the despite the general impact of Covid-19 on international migrants' return aspirations and decisions, its immediate impact on returning acts differs between types of migration (economic, humanitarian, transit, educational), migration status (temporary, seasonal, permanent); types of skills (low, high) and countries/regions. Also, these characteristics shape the possibilities for remigration to the destination country before pandemic or adopting in other ways.

For temporary migrant workers, the pandemic has a direct and indirect impact on returns. The loss of income and working/residence permit left no option to some migrants other than returning, as observed among South Asian migrants working in Gulf countries or East European migrants working in southern and western European countries. The pandemic has given momentum to some previously planned returns and onward migration to elsewhere, thus serving as a catalyst.

It may be anticipated that for highly-skilled migrants, including immigrant investors, the health system of the destination country may be a consideration in making migration and return decisions, although it was not a determining factor before. As desirable destinations such as the US and the UK showed slower and poorer performance in responding to the pandemic, this may deter migrants with high capital and lead them to re-evaluate alternatives such as Germany.

For asylum seekers and refugees, Covid-19 caused slowness in the asylum admissions/decisions and suspension of relocation and resettlement provisions for refugees given the public health situation of the host countries (Infomigrants, 2020). It temporarily suspended deportation of rejected asylum seekers in some European countries. It has not necessarily made asylum seekers and refugees consider return options due to the worse conditions in the country of origin and the increasing risk and costs of migrating. 
Table 10.2 Tentative typology of crisis-returns

\begin{tabular}{|c|c|c|c|c|}
\hline $\begin{array}{l}\text { Type of } \\
\text { migration }\end{array}$ & $\begin{array}{l}\text { Migration status } \\
\text { and levels of skills }\end{array}$ & $\begin{array}{l}\text { Immediate action at } \\
\text { the start of pandemic }\end{array}$ & Examples & $\begin{array}{l}\text { Aspirations for } \\
\text { re-migrating } \\
\text { after pandemic }\end{array}$ \\
\hline \multirow[t]{3}{*}{ Economic } & $\begin{array}{l}\text { Temporary \& Low } \\
\text { skills }\end{array}$ & $\begin{array}{l}\text { Either stranded or } \\
\text { waited in limbo, } \\
\text { returned }\end{array}$ & $\begin{array}{l}\text { Indian workers in } \\
\text { Gulf countries; } \\
\text { Venezuelans in } \\
\text { Colombia }\end{array}$ & $\begin{array}{l}\text { Plan to } \\
\text { re-migrate soon }\end{array}$ \\
\hline & $\begin{array}{l}\text { Seasonal \& Low } \\
\text { skills }\end{array}$ & Immediately returned & $\begin{array}{l}\text { Romanians in } \\
\text { Germany's } \\
\text { agriculture sector }\end{array}$ & $\begin{array}{l}\text { Already } \\
\text { re-migrated in } \\
\text { early summer } \\
2020\end{array}$ \\
\hline & $\begin{array}{l}\text { Permanent \& } \\
\text { Highly skilled }\end{array}$ & $\begin{array}{l}\text { Either expedited } \\
\text { return decision or } \\
\text { plan to return later }\end{array}$ & $\begin{array}{l}\text { Migrants working } \\
\text { in the private } \\
\text { sector or migrant } \\
\text { entrepreneurs in } \\
\text { UK, US }\end{array}$ & - \\
\hline Humanitarian & $\begin{array}{l}\text { Asylum seekers, } \\
\text { refugees, } \\
\text { undocumented } \\
\text { migrants in the } \\
\text { destination } \\
\text { countries }\end{array}$ & $\begin{array}{l}\text { Not plan to return } \\
\text { but may have been } \\
\text { forced to; risk further } \\
\text { irregularity and } \\
\text { xenophobia; } \\
\text { deportations resumed } \\
\text { in late summer } 2019\end{array}$ & $\begin{array}{l}\text { Irregular migrants } \\
\text { in Europe }\end{array}$ & - \\
\hline Transit & $\begin{array}{l}\text { Migrants on the } \\
\text { move }\end{array}$ & $\begin{array}{l}\text { Stranded in transit; } \\
\text { spontaneous or } \\
\text { assisted return if } \\
\text { resources found }\end{array}$ & $\begin{array}{l}\text { Afghans in Iran; } \\
\text { Nigerians in } \\
\text { Libya; Ethiopians } \\
\text { in Yemen }\end{array}$ & $\begin{array}{l}\text { Will re-migrate } \\
\text { given the } \\
\text { opportunity }\end{array}$ \\
\hline Education & Student visa & Immediately returned & $\begin{array}{l}\text { Students in } \\
\text { Canada, UK, } \\
\text { Australia }\end{array}$ & $\begin{array}{l}\text { Either } \\
\text { re-migrated to } \\
\text { destination or } \\
\text { continued } \\
\text { education by } \\
\text { distance }\end{array}$ \\
\hline
\end{tabular}

For irregular migrants on the move, it is difficult to claim that the pandemic makes the majority decide to return. Nevertheless, it indirectly triggers returns as it impedes the migration journey. It increases difficulty moving within transit countries or crossing borders, reduces access to smugglers, and increases costs, stranding irregular migrants in transits like those experienced in Libya, Niger, Kenya, and Yemen. While some become too afraid to either continue their journey or return home, others do not change their plans as a result of the pandemic, but simply wait out developments.

At the political level, the Covid-19 crisis met with highly nationalist government discourses and more restrictive immigration and mobility measures. At the social level, the feelings of suspicion surrounding immigrants and returnees were aggregated due to the perceived risk of the virus spread and growing economic challenges. There are too many shreds of evidence not to anticipate a possible surge in 
discrimination and xenophobia which might target migrants, thus prioritising return as a most desired option.

Neither well-planned voluntary returns nor quickly implemented forced returns or deportations necessarily mean the end of the migration journey. As earlier research on economic crises illustrates, many of the migrants continue to be the part of circular migration (both across countries and urban/rural) as the main motivations for migration - the need to earn income or escape persecution - persist, pushing millions to migrate. Most returnees are waiting and have not decided what they will do next. Showing similar characteristics with the global economic crisis, the pandemic has already intensified the struggles of labour.

Despite immediate migration restrictions, there is an ongoing demand for low wage migrants in labour-intensive sectors such as agriculture, meatpacking, processing, caregiving, and construction which are mainly populated by migrants. As Hanse Randal highlights, 'in a poorer world suffering major virus-inflicted structural damage, the demand for cheap labour - and cheap migrant labour - will only be stronger' (Hansen, 2020).

Acknowledgement Funding for writing this chapter has been provided by the Alexander von Humboldt Foundation, Experienced Researcher Fellowship.

\section{References}

Africanews. (2020, April 21). Coronavirus: Mozambican Workers Returning from South Africa Engaged to Check Covid-19's Spread.' https://www.africanews.com/2020/04/21/coronavirusmozambican-workers-returning-from-south-africa-engaged-to-check-covid-19-s-spread/

Apsite-Berina, E., Manea, M. E., \& Berzins, M. (2020). The ambiguity of return migration: Prolonged crisis and uncertainty in the life strategies of young Romanian and Latvian returnees. International Migration, 58(1), 61-75.

Arias, M. A., Ibanez, A. M., \& Querub, P. (2014). The desire to return during civil war: Evidence for internally displaced populations in Colombia. Peace Economics, Peace Science and Public Policy, 20(1), 209-223.

Babu, R. (2020). Covid-19: NRI Deaths Sully Kerala's Gulf Dream. Hindustan Times, June 25. Available at: https://www.hindustantimes.com/india-news/nri-deaths-sully-kerala-sgulfdream/story-nMoiqHEL1WLetlflDdVBIM.html. Accessed 1 July 2020.

Bascom, J. (2005). The long, 'last step'?: Reintegration of repatriates in Eritrea. Journal of Refugee Studies, 18(2), 165-180.

Butterly, L. (2020). Locked down and cast out: Europe's migrants navigate the pandemic. The Nation [online], April 15. https://www.thenation.com/article/world/eu-migration-covid/. Accessed 12 Nov 2020.

Buznego, M. E., Lee, A. E., \& Pérez, M. L. R. (2020). Class, gender and migration: Return flows between Mexico and the United States in times of crisis. Routledge.

Carling, J., \& Pettersen, S. V. (2014). Return migration intentions in the integration-transnationalism matrix. International Migration, 52(6), 13-30.

Cassarino, J. P. (2004). Theorising return migration: The conceptual approach to return migrants revisited. International Journal on Multicultural Societies (IJMS), 6(2), 253-279. 
Chang, D.-O. (2014). The global economic crisis and East Asian labour migration: A crisis of migration or struggles of labour? In A. Lindley (Ed.), Crisis and migration: Critical perspectives (Routledge Studies in Development, Mobilities and Migration) (pp. 93-114). Routledge.

De Bree, J., Davids, T., \& De Haas, H. (2010). Post-return experiences and transnational belonging of return migrants: A Dutch-Moroccan case study. Global Networks, 10(4), 489-509.

De Haas, H., \& Fokkema, T. (2010). Intra-household conflicts in migration decision making: Return and pendulum migration in Morocco. Population and Development Review, 36(3), 541-561.

De Haas, H., Fokkema, T., \& Fihri, M. F. (2015). Return migration as failure or success? Journal of International Migration and Integration, 16(2), 415-429.

Dickerson, C., \& Semple, K. (2020). U.S. deported thousands amid Covid-19 outbreak. Some proved to be sick. The New York Times [online], April 18. https://www.nytimes.com/2020/04/18/ us/deportations-coronavirus-guatemala.html. Accessed 12 Nov 2020.

Dumont, J. C., \& Spielvogel, G. (2008). Return migration: A new perspective. International Migration Outlook, 161-222.

Dustman, C. (2003). Children and return migration. Journal of Population Economy, 16, 815-830.

Endeshaw, D., \& Paravicini, G. (2020). U.N. says Saudi deportations of Ethiopian migrants risks spreading coronavirus. Reuters, April 13. https://www.reuters.com/article/us-healthcoronavirus-ethiopia-migrants/un-says-saudi-deportations-of-ethiopian-migrants-risksspreading-coronavirus-idUSKCN21V1OT.

EU Pact. (2020). EU Commission new pact on migration and asylum. Available at: https:// ec.europa.eu/info/strategy/priorities-2019-2024/promoting-our-european-way-life/new-pactmigration-and-asylum_en. Accessed 27 Dec 2020.

Eurofound. (2012). Labour mobility within the EU: The impact of return migration. European Foundation for the Improvement of Living and Working Conditions, Dublin, Ireland. Evidence from Multidimensional Educational Data. Norface Discussion Paper No. 2012018.

Frank, A. (2017). 'Voluntary' repatriation of rwandan refugees in Uganda: Between law and practice-views from below. Journal of Identity \& Migration Studies, 11(2).

George, M., Vaillancourt, A., \& Rajan, S. I. (2016). Sri Lankan Tamil refugees in India: Conceptual framework of repatriation success. Refuge: Canada's Journal on Refugees, 32(3), 73-82.

Gerver, M. (2018). Refugee repatriation and the problem of consent. British Journal of Political Science, 48(4), 855-875.

Gherasim, C. (2020). As restrictions lift, EU wants Romanian farm workers back. https://euobserver.com/coronavirus/148636.

Gulf News. (2020, April 12). Covid-19: Stranded expats in the UAE want to go home. https://gulfnews.com/opinion/editorials/covid-19-stranded-expats-in-the-uae-want-to-gohome-1.70940535.

Hansen, R. (2020). Covid-19 and the global addiction to cheap migrant labour. Open Democracy, October 6. https://www.opendemocracy.net/en/pandemic-border/covid-19-and-globaladdiction-cheap-migrant-labour/. Accessed 12 Nov 2020.

Holland, D., Fic, T. A., Rincon-Aznar, A., Stokes, L., \& Paluchowski, P. (2011). Labour mobility within the EU - The impact of enlargement and the functioning of the transitional arrangements (Final Report). Study for the DG Employment, Social Affairs and Inclusion, European Commission. National Institute of Economic and Social Research.

Iaria, V. (2014). Post-return transnationalism and the Iraqi displacement in Syria and Jordan. International Migration, 52(6), 43-56.

Infomigrants. (2020, March 18). Refugee resettlement suspended due to coronavirus. https:// www.infomigrants.net/en/post/23513/refugee-resettlement-suspended-due-to-coronavirus. Accessed 12 Nov 2020.

IOM. (2011). 'Return', IOM glossary on migration (2nd ed.). International Organization of Migration. https://www.corteidh.or.cr/sitios/Observaciones/11/Anexo5.pdf. Accessed 11 Nov 2020 
IOM. (2020). IOM Afghanistan Return of Undocumented Afghans, Situation Report, 05-11 April 2020. https://www.iom.int/sitreps/iom-afghanistan-return-undocumented-afghans-situationreport-05-11-april-2020. Accessed 11 Nov 2020.

IOM- Mogadishu. (2020, August 5). Somali migrants return home after several months stranded in Iran. https://www.iom.int/news/somali-migrants-return-home-after-severalmonths-stranded-iran.

IOM- N'Djamena. (2020, May 1). 'Covid-19 crisis: Over 2,000 stranded Chadian students return home through the EU-IOM Joint Initiative. https://www.iom.int/news/covid-19-crisisover-2000-stranded-chadian-students-return-home-through-eu-iom-joint-initiative.

IOM-Ulaanbaatar. (2020, August 11). IOM facilitates return of 185 Mongolians stranded in Czechia. https://www.iom.int/news/iom-facilitates-return-185-mongolians-stranded-czechia.

IOM-Abuja. (2020, August 18). Over 60 Nigerians return from Lebanon as migrant worker conditions worsens. https://www.iom.int/news/over-60-nigerians-return-lebanon-migrant-workerconditions-worsen.

IOM-Accra. (2020, February 11). IOM assists over 1,400 migrants with voluntary return to Ghana. https://www.iom.int/news/iom-assists-over-1400-migrants-voluntary-return-ghana.

IOM-Addis Ababa. (2020, August 11). IOM and Norwegian refugee council give assistance to thousands of COVID-19 returnee migrants in Ethiopia. https://www.iom.int/news/iom-andnorwegian-refugee-council-give-assistance-thousands-covid-19-returnee-migrants-ethiopia.

IOM-Algiers. (2020, July 17). Amid COVID-19 pandemic, IOM facilitates return of 84 migrants from Algeria to Mali. https://www.iom.int/news/ amid-covid-19-pandemic-iom-facilitates-return-84-migrants-algeria-mali.

IOM-Athens. (2020, July 8). Government of Greece Assist 134 Iraqi migrants with voluntary return. https://www.iom.int/news/iom-government-greece-assist-134-iraqi-migrants-voluntary-return.

IOM-Bamako. (2020, June 26). Stranded for three months, 338 Malians come home via humanitarian corridor. https://www.iom.int/news/stranded-three-months-338-malians-come-homehumanitarian-corridor.

IOM-Banjul. (2020, September 25). Voluntary returns from Niger to the Gambia resume after six-month hiatus. https://www.iom.int/news/voluntary-returns-niger-gambia-resume-after-sixmonth-hiatus.

IOM-Belize. (2020, July 7). IOM organizes double return flight between Belize and El Salvador. https://www.iom.int/news/iom-organizes-double-return-flight-between-belize-and-el-salvador.

IOM-Djibouti. (2020, September 9). Thousands of African migrants return from Yemen, assisted by IOM in Djibouti. https://www.iom.int/news/thousands-african-migrants-return-yemenassisted-iom-djibouti.

IOM-Freetown. (2020, August 14). Stranded Sierra Leoneans return amid Covid-19 pandemic, part of 2,800 returns along humanitarian corridors in West, Central Africa. https://www.iom. $\mathrm{int} /$ news/stranded-sierra-leoneans-return-amid-covid-19-pandemic-part-2800-returns-alonghumanitarian.

IOM-Honduras. (2020, May 5). IOM, USAID deliver 15,000 Covid-19 tests to Honduras. https:// www.iom.int/news/iom-usaid-deliver-15000-covid-19-tests-honduras.

IOM-Kampala. (2020, August 18). IOM supports voluntary return of Ugandan Women stranded in the Kingdom of Saudi Arabia. https://www.iom.int/news/ iom-supports-voluntary-return-ugandan-women-stranded-kingdom-saudi-arabia.

IOM-Nicosia. (2020, September 21). IOM and the Republic of Cyprus Assist 85 migrants with voluntary return. https://www.iom.int/news/iom-and-republic-cyprus-assist-85-migrantsvoluntary-return.

IOM-Niger. (2020, May 6). IOM Niger: Assisted Voluntary Return for Stranded Malians; Over 1,400 Remain in Transit Centers. https://www.iom.int/news/iom-niger-assisted-voluntary-returnstranded-malians-over-1400-remain-transit-centers.

IOM-Nigeria. (2020, October 6). Returning Nigerians are joining forces to start-up businesses back home. https://www.iom.int/video/returning-nigerians-are-joining-forces-startbusinesses-back-home. 
IOM-Pretoria. (2020, September 11). Stranded Malawian MIGRANTS RETURN HOME from South Africa. https://www.iom.int/news/stranded-malawian-migrants-return-home-south-africa.

IOM-Sudan. (2020, July 3). Sudan prepares to receive returning nationals. https://www.iom.int/ news/sudan-prepares-receive-returning-nationals.

Irudaya Rajan, S., \& Arokkiaraj, H. (2020). For Indian migrants in the Gulf it is a financial rather than a health crisis. Open Democracy, April 20. https://www.opendemocracy.net/en/ pandemic-border/indian-migrants-gulf-it-financial-rather-health-crisis/.

Kerpaci, K., \& Kuka, M. (2019). The Greek debt crisis and Albanian return migration. Journal of Balkan and Near Eastern Studies, 21(1), 104-119.

King, R. (Ed.). (2015). Return migration and regional economic problems. Routledge.

Koehler, J., Laczko, F., Aghazarm, C., \& Schad, J. (2010). Migration and the economic crisis in the European Union: Implications for policy (IOM Thematic Study). IOM.

Komireddi, K. (2020). 'Modi's India isn't prepared for the coronavirus. Foreign Policy, April 10. https://foreignpolicy.com/2020/04/10/modis-india-isnt-prepared-forthe-coronavirus/. Accessed 30 June 2020.

Koser, K., \& Kuschminder, K. (2017). Assisted voluntary return and reintegration of migrants: A comparative approach. A Long Way To Go, 255.

Kuttappan, R. (2020). Indians worry over UAE job losses. The Lede [Online]. https://www.thelede. in/inclusion/2020/04/01/indians-worry-over-uae-job-losses. Accessed 25 June 2020.

Lietaert, I. (2019). The usefulness of reintegration support: The dual perspectives of returnees and caseworkers. The British Journal of Social Work, 49(5), 1216-1233.

Lietaert, I., Broekaert, E., \& Derluyn, I. (2017). The boundaries of transnationalism: The case of assisted voluntary return migrants. Global Networks, 17(3), 366-381.

Lindley, A. (2015). Crisis and migration: Critical perspectives. Routledge.

Machnis-Walasek, J., \& Organiściak-Krzykowska, A. (2014). Return migration of higher educated poles in times of economic crisis. The Macrotheme Review: A Multidisciplinary Journal of Global Macro Trends, 3(2), 71-84.

Martínez-Buján, R. (2019). Here or there? Gendered return migration to Bolivia from Spain during economic crisis and fluctuating migration policies. Journal of Ethnic and Migration Studies, 45(16), 3105-3122.

McKee, M., \& Stuckler, D. (2020). If the world fails to protect the economy, Covid-19 will damage health not just now but also in the future. Nature Medicine, 26, 640-642.

Menon, D. V., \& Vadakepat, V. M. (2020). Migration and reverse migration: Gulf-Malayalees' perceptions during the Covid-19 pandemic. South Asian Diaspora, 1-21.

Mitra, R., Rawat, C., \& Varshney, G. (2020). Return migration and Covid-19: Data suggests Kerala, TN, Punjab, UP, Bihar may be future red zones for contagion risk. First Post [Online], April 14. https://www.firstpost.com/health/coronavirus-outbreak-return-migration-and-covid-19in-india-data-suggests-kerala-tamil-nadu-punjab-up-bihar-may-be-future-red-zonesfor-contagion-risk-8221531.html.

Mixed Migration. (2020). How is 4MI responding to the Covld-19 pandemic? http://www.mixedmigration.org/4mi/4mi_faq/.

MMC. (2020a). Covid-19 Global Update \#5-30 June 2020 impact of Covid-19 on refugees and migrants. http://www.mixedmigration.org/wp-content/uploads/2020/06/118_Covid_ Snapshot_Global_5.pdf.

MMC. (2020b). Covid -19 Global Update \#3-27 May 2020 impact of Covid-19 on refugees and migrants. https://drc.ngo/media/gpabsaqc/covid-19-gu-03.pdf.

MMC Asia. (2020). MMC Asia 4Mi Snapshot - July 2020 The impacts of Covid-19 on Afghans in India and Indonesia: Access to healthcare, livelihoods and support. http://www.mixedmigration.org/wp-content/uploads/2020/07/122_covid_snapshot_Asia.pdf.

MMC Asia-May. (2020). MMC Asia 4Mi Snapshot - Understanding the impact of Covid-19 on Afghans. http://www.mixedmigration.org/wp-content/uploads/2020/06/102_covid_snapshot_ asia.pdf. 
MMC Global. (2020). Covid -19 Global Update \#5-30 June 2020 Impact of Covid-19 on refugees and migrants. http://www.mixedmigration.org/wp-content/uploads/2020/06/118_Covid_ Snapshot_Global_5.pdf.

Munasinghe, H. (2020). Return migration during a pandemic. https://contexts.org/blog/ inequality-during-the-coronavirus-pandemic/\#hans.

Omata, N. (2013). The complexity of refugees' return decision-making in a protracted exile: Beyond the home-coming model and durable solutions. Journal of Ethnic and Migration Studies, 39(8), 1281-1297.

Polanco, A., \& Sequera, V. (2020). Venezuelan migrants quarantined in crowded shelters as they return home. Reuters, April 7. https://www.reuters.com/article/us-health-coronavirusvenezuela-migrants/venezuelan-migrants-quarantined-in-crowded-shelters-as-they-returnhome-idUSKBN21P361.

Premkumar, S. (2020). The Gulf Boomerang: India's biggest reverse migration from a world devastated by Covid-19'. https://www.outlookindia.com/magazine/story/india-news-the-gulfboomerang-indias-biggest-reverse-migration-from-a-world-devastated-by-covid-19/303219.

Pusti, Z. J. (2013). Persistence in recession: Return migration during the economic crisis in Spain. Central European University.

RFE. (2020, February 20). Plane carrying Ukrainians arrives from China's Wuhan Amid protests. https://www.rferl.org/a/plane-carrying-ukrainians-arrives-from-china-s-wuhan-amidprotests/30445316.html.

Roman, M., \& Goschin, Z. (2014). Return migration in an economic crisis context. A survey on Romanian healthcare professionals. Revista Romana de Economie, 39(2).

Ruben, R., Van Houte, M., \& Davids, T. (2009). What determines the embeddedness of forcedreturn migrants? Rethinking the role of pre-and post-return assistance. International Migration Review, 43(4), 908-937.

Saar, M. (2018). To return or not to return? The importance of identity negotiations for return migration. Social Identities, 24(1), 120-133.

Sabharwal, M., \& Verma, R. (2020). Transnationalism and return migration of scientists and engineers from the United States to India. In A. K. Sahoo \& B. Purkayastha (Eds.), Routledge handbook of Indian transnationalism (pp. 53-66). Routledge.

Scollon, M. (2020, April 15). Covid-19 a hard row to Hoe for migrant laborers. https://www.rferl. org/a/covid-19-migrant-laborers-russia-central-asia/30557391.html.

Skrentny, J. D., Chan, S., Fox, J., \& Kim, D. (2007). Defining nations in Asia and Europe: A comparative analysis of ethnic return migration policy 1. International Migration Review, 41(4), 793-825.

Smith, M. T. (2019). Migration management, global migration governance, and the case of the International Organization for Migration's assisted voluntary return and reintegration programming. Doctoral dissertation, University of Delaware.

Smoliner, S., Förschner, M., Hochgerner, J., \& Nová, J. (2012). Comparative report on re-migration trends in Central Europe. Re-Turn, Centre for Social Innovation, Vienna, 81.

Travel News. (2020). UAE extends validity of residency and visit visas till the end of 2020. https:// timesofindia.indiatimes.com/travel/destinations/uaeextends-validity-of-residency-and-visitvisas-till-the-end-of-2020/as75137540.cms

UN Compact. (2018). Global compact for safe, orderly and regular migration. UN General Assembly, A/RES/73/195. Resolution adopted by the General Assembly on 19 December 2018. Available at: https://www.un.org/en/ga/search/view_doc.asp?symbol=A/RES/73/195. Accessed 27.12.2020.

Waldorf, B. (1995). Determinants of international return migration intentions. The Professional Geographer, 47(2), 125-136.

Wang, W. W., \& Fan, C. C. (2006). Success or failure: Selectivity and reasons of return migration in Sichuan and Anhui, China. Environment and Planning A, 38(5), 939-958.

Zachariah, K. C., \& Rajan, S. I. (2010). Impact of the global recession on migration and remittances in Kerala: New evidence from the Return Migration Study. (RMS) 2009. 
Zaiceva, A., \& Zimmermann, K. F. (2012). Returning home at times of trouble? Return migration of EU enlargement migrants during the crisis. IZA and Bonn University Discussion Paper No. 7111 December 2012. Available at: http://ftp.iza.org/dp7111.pdf.

Zeeshan, M., \& Sultana, A. (2020). Return migration to Pakistan during Covid-19 pandemic: Unmaking the challenges. Pakistan Perspectives, 25(1 January-June). Available at: SSRN: https://ssrn.com/abstract=3697875

Open Access This chapter is licensed under the terms of the Creative Commons Attribution 4.0 International License (http://creativecommons.org/licenses/by/4.0/), which permits use, sharing, adaptation, distribution and reproduction in any medium or format, as long as you give appropriate credit to the original author(s) and the source, provide a link to the Creative Commons license and indicate if changes were made.

The images or other third party material in this chapter are included in the chapter's Creative Commons license, unless indicated otherwise in a credit line to the material. If material is not included in the chapter's Creative Commons license and your intended use is not permitted by statutory regulation or exceeds the permitted use, you will need to obtain permission directly from the copyright holder.

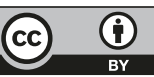

